Bochenek M., The issue of economic crises and cyclical fluctuations in Polish economic thought in the interwar period, „Ekonomia i Prawo. Economics and Law”, Polszakiewicz B., Boehlke J. (ed.), Vol. 15, No. 1/2016, pp. 7-19. DOI: http://dx.doi.org/10.12775/EiP.2016.001.

\author{
MIROSŁAW BOCHENEK
}

\title{
THE ISSUE OF ECONOMIC CRISES AND CYCLICAL FLUCTUATIONS IN POLISH ECONOMIC THOUGHT IN THE INTERWAR PERIOD
}

\author{
SUMMARY
}

This paper presents the considerations of Polish economists about the economic crises and the business cycle in the interwar period. According to E. Taylor, the causes of the then crisis of overproduction, accompanied by the phenomenon of price scissors, included varied elasticity of demand for agricultural products and industrial products, as well as monetary inflation and new technical inventions. E. Lipiński believed that the crisis was a result of overinvestment. State interventionism in the economies did not ease, but aggravated the crisis on a global scale. W.M. Zawadzki pointed to the nature of the crisis in Poland as being due to economic underdevelopment, low consumption, and a huge shortage of capital. J.W. Libicki took the view that an analysis of the crisis in agriculture should be combined with an analysis of profitability of agricultural production. A. Krzyżanowski linked production fluctuations with changes in investment demand, and the latter with the assessment of profitability, which depends on the interest rate. A. Heydel explained the business cycle with an incorrect interest rate policy. At the same time, he postulated that the state should refrain from interference in economic life. On the other hand, M. Kalecki pointed to the excessive optimism of businesses, causing an increase in investment, which leads

Mirosław Bochenek, Nicolaus Copernicus University, Faculty of Economic Sciences and Management, Department of Economics, ul. Gagarina 13A, 87-100 Torun, Poland, phone: +48 5661148 96, e-mail: bochenek@econ.umk.pl. 
to changes in global demand, as a cause of fluctuations. He advocated the inflationary financing of public works by the state.

Keywords: history of economic thought; theories of economic crises; theories of the business cycle

JEL Classification: B20; E32

\section{INTRODUCTION}

The issues of economic crises caused by overproduction became a subject of academic reflection of economists after the occurrence of this phenomenon, i.e. in the early $19^{\text {th }}$ century. Soon, these issues were also taken up by Polish researchers into economic problems, including August Cieszkowski, Leon Winiarski, Julian Marchlewski, Róża Luksemburg, and Jerzy Heryng. This means that the studies of Polish economists in this area already have more than a 150-year history. Concern for the world economic situation in the first decades of the $20^{\text {th }}$ century was also reflected in Polish economic thought. A large group of Polish academics also responded to the outbreak of the Great Depression of 1929-1933. This study is devoted to the presentation of their views. It includes a selection of reflections on the causes and course of the economic crisis, the agrarian crisis, and the economic cycle. However, given the scope of this article, not all publications on these topics have been taken into account; the considerations of Roman Rybarski, Jan Piwowarczyk, Ferdinand Zweig, Feliks Młynarski, and Oskar Lange have been omitted. The method of historical analysis has been applied.

\section{ECONOMIC CRISES}

The causes and course of the economic crisis called the Great Depression were dealt with particularly by E. Taylor, E. Lipiński, and W.M. Zawadzki.

In his article Istota kryzysu swiatowego (The Essence of the Global Crisis, 1931), Edward Taylor, representing the neoclassical school, drew attention to the need for the reconstruction of what is known as J.B. Say's law of markets which is about the impossibility of general overproduction. According to E. Taylor, in order to explain the current crisis the concept of elasticity of demand had to be applied. It shows that various types of goods are characterized by a different elasticity of demand. Empirical studies indicated that the demand for agricultural products is more rigid than the demand for industrial products. A period of steady production growth must be followed by 
a lack of sales and falling prices in the whole economy. And since agricultural production has lower elasticity of demand, overproduction initially occurs in agriculture. The decline in the purchasing power of the agricultural sector results in a decline in the demand for industrial products, generating the phenomenon of general overproduction. The level of prices of industrial products remains at a higher level than the level of prices of agricultural products. This phenomenon is called the opening of price scissors, which is part of the economic crisis involving general overproduction. The emergence of relative overproduction in agriculture was the result of taking up the cultivation of new areas in new countries and intensifying production in Europe and North America. Financed through budget inflation, the increase in general overproduction worldwide, which was faster than the population growth, was accompanied by an increase in consumption and investment, which further stimulated the development of production. Among the reasons for the collapse of the current economic situation, E. Taylor also counted the disparities between the circulation of money and the amount of capital caused by monetary inflation, and the disruption of the increased inflationary process that had begun during the First World War. An important cause of the crisis was also the fast pace of epoch-making inventions and technological advances that revolutionized industry, and accelerated the industrialization of Western countries, as well as increasing world production. Due to the depth of the crisis analysed and the need for a thorough reconstruction of economic life, E. Taylor foresaw the development of a new system of global economic relations, which would be a long process. One of the features of this transformation would be the entering on the industrial path of new countries, rich in natural resources and cheaper labour, which - ensuring higher profitability - would attract the missing capital and industrial culture. According to E. Taylor, the geographical displacement of economic life centres would also occur ${ }^{1}$.

Edward Lipiński, who was a supporter of neoclassical economics, presented his explanation of the crisis phenomena which may be caused by overinvestment in a paper entitled Uwagi o kryzysie (Some Remarks About the Crisis, 1931). He explained, however, that certain conditions must occur for excess investments to lead to the outbreak of a crisis. Overinvestment occurs when the production of manufacturing equipment, i.e. capital goods or other investment goods, exceeds the real demand for these goods. The demand of some branches for these devices depends mainly on their prices. Organizing their

E. Taylor, Istota kryzysu światowego, "Ruch Prawniczy, Ekonomiczny i Socjologiczny", Vol. 4/1931, pp. 314-324. 
production, manufacturing facilities select the factors of production in a team (comprehensive) manner. Their optimality is guaranteed by the law of harmony. All devices must be selected in correct proportions. Producing even a single machine or device in excess means overinvestment. Each pointless investment constitutes a socio-economic loss. What is more, the means of production that could be used to produce consumer goods are consumed in order to aimlessly produce these unnecessary devices. In a capitalist economy, these ill-judged investments inevitably cause a crisis whose manifestation is the lack of sales of goods at the prices calculated earlier. Products manufactured in excess will also be sold, but a little later, and at a lower price. This adjustment of supply and demand requires a transitional period, which is a crisis. Lower prices of investment goods reduce the purchasing power of their producers, who limit their demand for the factors of production consumed by them. The imbalance appearing in one market moves into other markets, and so the crisis spills over a number of interrelated markets. Economic recovery, i.e. an increased investment flow, is caused by (cyclical) changes in the economic situation, and these are the result of the dynamic nature of a social economy. However, there would be no dynamics, growth, development, or economic recovery, if no changes in the credit offer occurred. Credit expansion stimulates the will to expand investment. According to E. Lipiński, these are two factors that cause cyclical changes in the economy, as well as two factors taken into account by economic theory. The recovery from the years 1927-1928, which preceded the outbreak of the crisis in Poland, had its source in both private (but mostly by foreign companies) and state excess capitalization. The excessive increase in investment in our country was also caused by Bank Polski (the Polish Bank), which charged on their loans an interest rate 3 times lower than the one prevailing on the private market. A factor responsible for the outbreak of the crisis was also government interventionism (although recognized as a necessity of the development of modern capitalism) blocking, according to E. Lipiński, the activity of economic automatism, which in the early stages of capitalism maintained economic equilibrium. Through the introduction of minimum prices and protective tariffs, states exacerbated the crisis on a world scale. Any interference in the economy, be it by the state, or by a cartel, leads to a temporary or permanent imbalance ${ }^{2}$. E. Lipiński wrote: "The whole mechanism that regulates balance is thus broken. One could put forward a proposition that the current economic crisis is a result of the gradual shift from market capitalism, that is a capitalism in which market phenomena are a regulator of balance, to planned or regulated capitalism. However,

${ }^{2}$ E. Lipiński, Uwagi o kryzysie, “Ekonomista”, Vol. 1/1931, pp. 20-31. 
since planning and regulating are performed only in one section, and not in the whole business, we face a much sharper slump in balance than in periods when the market mechanism worked more efficiently, and thus the correction of the market was more direct and earlier. Also, the duration of periods of adaptation is now longer since individual components of the market structure have lost flexibility. Hence, the need for a long period of adaptation of the remaining components to the changed constellations of market quantities" 3 .

On the other hand, standing on the grounds of the mathematical school, Władysław Marian Zawadzki took the view that while the Polish economic crisis consisted of phases similar to those observed in other countries, there were, however, significant differences in the phenomena accompanying it. To a large extent, they resulted from the economic underdevelopment of our country. In addition, the economic crisis in Poland occurred at the end of 1928 due to the drop in agricultural commodity prices on the world market, which slowed down the pace of the economy in the following year. Most of the symptoms of depression occurred at the end of 1929, and deepened the next year. They corresponded to the phenomena accompanying the recession phase of the classic business cycle, such as a decline in industrial production, bankruptcy of enterprises, rising unemployment, falling stock prices, etc. In 1930, a normal course of the cycle and the imminent arrival of the recovery phase was anticipated. In the following months, however, a deepening of the depression followed. Banks applied an extremely stringent credit policy, reducing almost completely access to credit. This in turn hampered the sales of products, and caused a drop in income, which intensified the negative effects of the crisis. Production fell by approx. 50\%, and the unemployment rate reached $32 \%$. The breakthrough came only after four years, i.e. in 1933 which saw a slight improvement in economic indicators. According to W.M. Zawadzki, the explanation of the specifics of the Polish crisis using credit money creation theory was very difficult since the Polish banking system was underdeveloped and, therefore, deposit banks did not generate credit money. Hence, Polish banks caused neither depression, nor recovery. A similar role was played by foreign loans. Furthermore, deflationary measures cannot be considered as a cause of the crisis; deflation was rather a consequence of the crisis ${ }^{4}$. W.M. Zawadzki asserted, "Thus, it seems unde-

3 Ibidem, pp. 31-32.

${ }^{4}$ W. Zawadzki, Przesilenie gospodarcze w świetle doświadczeń polskich, [in:] Pamiętnik trzydziestolecia Szkoty Gtównej Handlowej w Warszawie 1906-1936, SGH, Warszawa 1938, pp. 200-208. 
niable that the phenomena of money circulation and credit are not sufficient to explain either the reasons for, or, all the more, the exceptionally long duration and severity of, the crisis" . John Maynard Keynes's theory of underconsumption also proved to be of little use. The Polish economy was characterized by low consumption, much lower than in Western European countries, and a high ratio of consumption to income, which led to the possibility of increasing production. There was also the possibility of implementing a large number of investment projects, but our country suffered a huge shortage of capital. However, in J.M. Keynes's theory, capital employed must reach high marginal performance, causing economic recovery. According to the author of Przesilenie gospodarcze w świetle doświadczen polskich (The Economic Crisis in the Light of Polish Experience), the case of our country showed clearly that there were some specific factors that caused and prolonged the economic crisis. These were the previously mentioned phenomena such as insufficient capital resources and inadequate proportions between solid and liquid capital. The Vilnius academic included money and real savings, comprising easily exchangeable goods, in liquid capital. Unfortunately, at that time, liquid capital in the aforementioned sense did not exist in the Polish economy. In the pre-crisis period, Polish society increased consumption, but it failed to make sufficient savings, hence, their absence prevented merchants and industrialists from keeping larger supplies of finished goods and raw materials. Fluctuations in production and sales froze the existing capital. Thus, the lack of working capital experienced by entrepreneurs reduced both production and sales, closing the vicious circle of depression. Contrary to J.M. Keynes's assertions, it was the lack of savings that caused and exacerbated the Polish economic crisis ${ }^{6}$.

On the other hand, in his article under the title Zagadnienie pañstw rolnych Europy Srodkowej i Wschodniej (The Issue of Agricultural Countries of Central and Eastern Europe, 1932), W.M. Zawadzki stressed that the great depression differed significantly from the economic crises occurring earlier. A feature of the great downturn was its universality and a very deep depression, regardless of the strength and nature of the economy. He also claimed that international economic cooperation could have been an effective way to fight the Great Depression. It would concern especially agricultural countries, for

\footnotetext{
5 Ibidem, p. 208.

${ }^{6}$ Ibidem, pp. 208-211.
} 
which a necessary condition for economic recovery was to open both external and domestic markets ${ }^{7}$.

\section{THE AGRARIAN CRISIS}

An interesting discussion of the agrarian crisis from a theoretical point of view was undertaken by a representative of the neoclassical school, Wojciech Janusz Libicki, in his article under the title Kleska urodzaju (The Curse of Abundance, 1931). In his opinion, the relationship between a good (or bad) harvest and yields of agricultural production, especially plant production, should be taken into account in explaining the problem of overproduction in agriculture. At the same time, the author of the article assumed that there is free competition and one price on the market. Undertaking business activity, a rational entrepreneur is driven only by profit. In order to calculate profitability, it is necessary to know the unit price and unit cost of production. But agricultural producers, as opposed to an industrial manufacturer, do not know either future prices, or unit costs. It follows that they can calculate total costs, but they are unable to predict the size of future produc$\operatorname{tion}^{8}$. J.W. Libicki wrote: "The total costs incurred during the production period are constant, regardless of its outcome. Thus, the unit cost varies inversely to crops results. The better the yield, the lower the unit cost, and the other

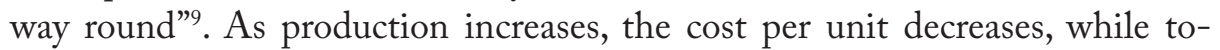
tal costs, which also include the land rent, grow. In turn, the demand curve (which is also the price curve) takes the shape of a descending curve with different degrees of flexibility. The intersection point of the unit costs curve and the price (demand) curve designates the point of equilibrium, which sets the free market price and the volume of production ensuring profitability. Above this quantity, agricultural entrepreneurs suffer losses, while below it they make an extraordinary profit. Changes in prices can, however, be compensated by shifts in the demand curve. Good or bad crops shift the demand curve and the equilibrium point. For an individual agricultural farm, however, price is a fixed quantity. Good crops, i.e. achieving a good result, provide a farm with an extra profit, while crop failure (a weaker performance) re-

${ }^{7}$ W. Zawadzki, Zagadnienie państw rolnych Europy Środkowej $i$ Wschodniej, "Polska Gospodarcza", Vol. 35/1932, p. 1010.

8 J. Libicki, Klęska urodzaju, "Ruch Prawniczy, Ekonomiczny i Socjologiczny", Vol. 2/1931, pp. 206-207.

\footnotetext{
${ }^{9}$ Ibidem, p. 207.
} 
sults in a loss. An extremely positive phenomenon for an individual agricultural farm is a good harvest and a shift, due to the smaller crops in the rest of the world, of the horizontal straight line of prices upwards, while a negative phenomenon is a bad harvest, accompanied by a fall in prices resulting from a good harvest in the rest of the world. Based on the analysis performed, the author of The Curse of Abundance formulated the conclusion that good harvest and crop failures in agriculture produce opposite effects for the national economy and individual farms. The views on the curse or the blessing of abundance should rather be regarded as meaningless platitudes. It is reasonable to consider these phenomena in a broader context, a wider complex of phenomena ${ }^{10}$.

\section{THE BUSINESS CYCLE}

The issue of cyclical fluctuations in production raised considerable interest among Polish economists. Publications by A. Krzyżanowski, A. Heydel, and M. Kalecki are especially noteworthy.

Representing the neoclassical school, Adam Krzyżanowski presented his theory of the business cycle in several studies, among others in Polska konjunktura gospodarcza w swietle teorji przesileń i przewidywań (The Polish Economic Situation in the Light of the Theory of Crises and Projections, 1929), and Teorja $i$ polityka oszczednosici (The Theory and Politics of Saving, 1931). Similarly to Gustav Cassel's theory, it is a theory of overinvestment. A. Krzyżanowski assumed that monetary and credit factors have a significant impact on the course of the business cycle. Mood swings and viability assessments result in changes in production volumes. The profit rate and interest rate affect changes in the demand for means of production (investment) and savings, and these lead to fluctuations in production. Profitability fluctuations, leading to cyclical fluctuations, disrupt the balance, but these phenomena stimulate the mechanisms that lead the economy towards equilibrium. This regularity occurs in any dynamic economy. In contrast, economic growth is a result of automatic, unfettered activities of economic entities, which should not be hindered by any form of state interference. The pace of economic growth depends on the rate of accumulation, and this depends on the rate of profit and competitiveness. The main brake on growth is insufficient savings ${ }^{11}$.

10 Ibidem, pp. 208-218.

11 A. Krzyżanowski, Polska konjunktura gospodarcza w świetle teorji przesileń i prze-widywań, Nakładem Krakowskiej Spółki Wydawniczej, Kraków 1929, p. 13 and next.; A. Krzyżanowski, 
In turn, in his considerations of the economic situation, Adam Heydel, a supporter of the psychological school, observed that from a theoretical point of view endogenous economic theories are of more value than exogenous ones. The author of the article under the title Teorja konjunktury (The Theory of the Economic Situation, 1929) pointed out that the main reason for cyclical fluctuations in production is the inappropriate interest rate policy of banks, through excessive currency issuance. A low interest rate causes investment boom, disproportions between fixed and working capital occur, and inflation accelerates. Thus, inflation results in disparities in economic life. Keeping the bank interest rate at the market rate level is the most effective way to stabilize the economic situation. In his opinion, however, due to the short history, greater educational value should be granted to empirical research rather than theoretical speculation in explaining the crises and fluctuations of the economic situation ${ }^{12}$.

A. Heydel devoted his article under the title Kryzys, interwencja i etatyzm (The crisis, intervention, and statism, 1931) to the crisis understood not as a collapse of prosperity, but as the depression experienced by the world economy since 1929. Among various crises he distinguishes those of scarcity and of excess. Crises of scarcity are caused by catastrophic crop failures, revolutions, and wars, and therefore non-economic factors that economics cannot explain, and which it cannot heal. Economics is interested in crises of excess caused by economic factors that lead to an apparent abundance of goods. Crises of excess include cyclical and structural crises, however, the differences between them are difficult to explain. Cyclical crises are repeated with a 6-to-10-year regularity, whereas structural crises are caused by changes in management conditions. Economists have identified a range of extra-cyclical causes that trigger off crises. Gustav Cassel pointed to the lack of gold and inappropriate distribution of this material between countries. According to another hypothesis, advocated by Roman Dmowski and Edward Taylor, the crisis of 1929 was triggered off by industrial hyperproduction, generated by competition from Asian countries, which employed cheap workforces. Since this crisis occurred nine years after the depression of 1920, A. Heydel held that cyclical factors were responsible for the 1929 crisis. Just as in his earlier work entitled Teorja konjunktury (The Theory of the Economic Situation), he stated that only monetary theory adequately explains the fluctuation of economic life. According

Teorja i polityka oszczędności, Nakładem Rady Zjazdów Instytucyj Oszczędnościowych w Polsce, Warszawa 1931, p. 11 and next.

12 A. Heydel, Teorja konjunktury, Odbitka z Pamiętnika I Zjazdu Ekonomistów Polskich, Poznań 1929, pp. 1-28. 
to this theory, whose supporter was also the author of Crisis, Intervention and Statism, the low interest rate policy pursued by emission and depository banks is responsible for recovery and depression. In addition, A. Heydel believed that the level of interest rates should be shaped spontaneously by the ratio of demand for capital and the supply of capital, at a level balancing the capital market. However, it is arbitrarily fixed by people directing financial institutions, in isolation from the whole of economic life. If the level of interest rates is determined freely by any institution as an intervention in the economy, then it ceases to function as a regulator of economic life, and even causes its disturbance. With too low an interest rate, saving money becomes unprofitable, as opposed to investments which generally increase, causing excessive recovery. This recovery period does not last too long, and after its collapse it is followed by a period of depression. A. Heydel emphasized his belief that interventions in the financial markets are the cause of economic crises and fluctuations. The most plausible theory explaining these phenomena is monetary theory. During the crisis, the economy returns to an equilibrium. This process is usually accompanied by frictions. Interventionism and statism not only prolong the transitional period, i.e. the period of rebalancing, but also move the economy away from equilibrium. Thus, stiffening economic mechanisms, interventionism and statism lead to the intensification of the crisis and the strengthening of frictions ${ }^{13}$. A. Heydel wrote: "It is not capitalism or liberalism, which it is difficult to reproach for not existing, that fail; it is intervention and statism that do so" ${ }^{14}$. The limitation of liberalism leads to the deepening and prolonging of a crisis. "In the hands of managers of economic policy there is a reliable measure, which must accelerate the recovery of economic life, and it is the loosening of the bonds restricting economic life. Quite a lot has to be done about it in Poland. A drop in customs duties, which would force cartels to cut their stiffened prices, a change in the policy of the Ministry of Labour (...), a prominent drop in state and local government budgets, rather reducing the number of officials and state employees than lowering their salaries, a fundamental change in our interest rate policy - these are the measures that will certainly accelerate the return of the Polish economy to equilibrium. Life itself will slowly restore it"15.

An original theory of the business cycle, expressed in the language of mathematics, was announced in 1933 by Michał Kalecki, standing on the ground of Marxist economics, in his treatise under the title Próba teorii

\footnotetext{
${ }^{13}$ A. Heydel, Kryzys, interwencja i etatyzm, "Ekonomista", Vol. 1/1931, pp. 3-17.

${ }^{14}$ Ibidem, p. 17.

15 Ibidem, p. 18.
} 
koniunktury (An Attempt at Economic Situation Theory). In his view, the source of economic fluctuations in the capitalist economy is the investment processes and excessive optimism of companies, which lead to an excessive increase in the quantity of means of production. The extension of the production apparatus is greater than actual consumption. The difficulties in selling reduce the utilization of production factors, profitability drops, which results in reduced investment and employment followed by the outbreak of a crisis. Therefore, investments are a source of the crisis and unemployment in capitalism. The way out of the crisis is not cutting real wages, causing a drop in demand, but the inflationary financing of public works. Rejecting Say's Law, which speaks about the creation by supply of its own demand, Kalecki concluded that the capitalist economy does not achieve balance automatically. It follows that in Kalecki's theory production and income depend on global demand, especially on the investment expenditures incurred by business$\mathrm{es}^{16}$. Although Kalecki developed business cycle and employment theories, in which production is determined by global demand, earlier and more accurately than John Maynard Keynes, priority is obviously wrongly attributed to the British economist, not to the Polish one. The reason was making the treatise available to Western economists rather late. Its simplified and shortened version Istota poprawy koniunkturalnej (The Essence of the Economic Upswing, 1935), originally published in "Polska Gospodarcza", was published in the "Econometrica" magazine only in 1935 as A Macrodynamic Theory of Business Cycles. In contrast, the full text of An Attempt in English appeared only in 1939 under the title Essays in the Theory of Economic Fluctuations. Kalecki continued his research in this field in subsequent years. It culminated in the book under the title Theory of Economic Dynamics: An Essay on Cyclical and Long-Run Changes in Capitalist Economy (1954), in which he presented a developed theory of the business cycle ${ }^{17}$.

${ }^{16}$ M. Kalecki, Próba teorii koniunktury, [in:] M. Kalecki, Dzieta, Vol. 1: Kapitalizm. Koniunktura $i$ zatrudnienie, PAN - PWE, Warszawa 1979, pp. 95-157. The most important part of this work was reissued 30 years later as An Outline of Economic Situation Theory. M. Kalecki, Prace z teorii koniunktury 1933-1939, PWN, Warszawa 1962, pp. 9-26.

${ }_{17}$ M. Kalecki, Teoria dynamiki gospodarczej. Rozprawa o cyklicznych i dtugofalowych zmianach gospodarki kapitalistycznej, PWN, Warszawa 1986, p. 137 and next. 


\section{CONCLUSIONS}

The above views of selected Polish economists about economic crises and the business cycle, propagated in the interwar period allow the drawing of some conclusions. Shortly after the outbreak of the Great Depression, Polish academics attempted to explain its causes, and formulated a number of recommendations for economic policy. Between their views we can observe considerable differences, resulting mainly from the different economic schools represented, and the scope of research. As sources of the crisis they recognized, among others, diversified elasticity of demand for agricultural and industrial products, monetary inflation, new technical inventions, excessive investment, as well as economic underdevelopment, and a shortage of capital. In their explanation of the business cycle, they pointed to changes in the quantity of investment demand, interest rate policy, and the optimism of companies. The limiting of state interference in economic life dominated among the postulates for stabilization policy, whereas the proposal to conduct public works belonged to exceptions. E. Taylor's, E. Lipiński's, W.M. Zawadzki's, A. Krzyżanowski’s, A. Heydel's, and M. Kalecki's considerations about crises and business cycles covered the whole economy, while the works of J.W. Libicki aimed at one of its sectors. The former group of considerations is therefore more useful for analyses of a macroeconomic nature, while the latter for mesoeconomic analyses. It is regrettable that after the outbreak of the crisis in 2008 many Polish economists invoked only the views voiced by representatives of the Austrian school, Keynesianism, monetarism, and new classical economics, but omitted the diverse and original Polish economic thought of the interwar period, which was the equal of the Western thought.

\section{BIBLIOGRAPHY}

Heydel A., Kryzys, interwencja i etatyzm, "Ekonomista", Vol. 1/1931.

Heydel A., Teorja konjunktury, Odbitka z Pamiętnika I Zjazdu Ekonomistów Polskich, Poznań 1929.

Kalecki M., Prace z teorii koniunktury 1933-1939, PWN, Warszawa 1962.

Kalecki M., Próba teorii koniunktury, [in:] M. Kalecki, Dzieta, Vol. 1: Kapitalizm. Koniunktura i zatrudnienie, PAN - PWE, Warszawa 1979.

Kalecki M., Teoria dynamiki gospodarczej. Rozprawa o cyklicznych i dtugofalowych zmianach gospodarki kapitalistycznej, PWN, Warszawa 1986.

Krzyżanowski A., Polska konjunktura gospodarcza w świetle teorji przesileń i przewidywań, Nakładem Krakowskiej Spółki Wydawniczej, Kraków 1929. 
Krzyżanowski A., Teorja i polityka oszczędności, Nakładem Rady Zjazdów Instytucyj Oszczędnościowych w Polsce, Warszawa 1931.

Libicki J., Klęska urodzaju, "Ruch Prawniczy, Ekonomiczny i Socjologiczny", Vol. 2/1931.

Lipiński E., Uwagi o kryzysie, "Ekonomista”, Vol. 1/1931.

Taylor E., Istota kryzysu światowego, "Ruch Prawniczy, Ekonomiczny i Socjologiczny", Vol. 4/1931.

Zawadzki W., Przesilenie gospodarcze w świetle doświadczeń polskich, [in:] Pamiętnik trzydziestolecia Szkoty Gtównej Handlowej w Warszawie 1906-1936, SGH, Warszawa 1938.

Zawadzki W., Zagadnienie państw rolnych Europy Środkowej i Wschodniej, "Polska Gospodarcza", Vol. 35/1932. 
